\title{
A Study On The Relationship Between Exhibition Experience And Behavioral Intention, And The Mediating Effect Of Satisfaction And Brand Assets In Corporate Promotion Exhibition Halls
}

\author{
Ju Seung-Wan ${ }^{1^{*}}$ \\ ${ }^{1}$ Department of Financial Accounting/Real Estate, Dong-Eui University, Korea
}

Article History: Received:11 January 2021; Accepted: 27 February 2021; Published online: 5 April 2021

\begin{abstract}
Currently, Korean companies operate corporate promotion halls, memorial halls and museums, centering on large corporations, making them a place for long-term communication beyond the short-term contact with consumers. In addition, companies have provided recently virtual exhibition experiences through the homepage or apps to the corporate publicity exhibition halls, which are operated by the company, and are being developed in parallel with the existing exhibition experiences. Therefore, this study conducted an empirical analysis to find out the effect of the exhibit experience of the corporate publicity exhibition hall on the consumer behavioral intention with the subject of the visitors who have experienced the exhibition experience of the domestic corporate publicity exhibition hall. Followings are the implications for the results. First, the corporate publicity exhibition hall did not have a specific effect on the behavioral intention of customers simply by exhibiting and viewing. This indicates that companies that operate or prepare to open the corporate publicity exhibition hall should avoid such simple experiences or simple viewing facilities. Second, the corporate publicity exhibition hall cannot induce customers' behavior simply by exhibiting experiences. The results will be more efficient when the corporate publicity exhibition hall is operated in combination with the brand assets of the company presented in this study or tangible and intangible assets of other companies. Third, as derived from the results of the study, corporate product brands are boldly exposed to consumers and very sensitive to consumers, affecting their behavioral intentions. The positive image of a product brand will lead to satisfaction and behavioral intentions, which in turn will affect the company's sales growth. Therefore companies should be very careful in managing their product brand. The academic significance of this study is in that it investigated the relationship between satisfaction, brand assets, and behavioral intention through the exhibition experience in the corporate publicity exhibition hall by conducting empirical analysis of the relationship systematically. In addition, it is expected to be used as a practical basic material that can be more practical in producing exhibition experiences when newly opening a corporate publicity exhibition hall or remodeling an existing corporate publicity exhibition hall. In the follow-up study, in order to provide the best exhibition experience to visitors to a company publicity exhibition hall, various variables such as human and material elements of the company publicity exhibition hall, such as how to guide at an information desk, the contact point with customers as well as four elements of experience. In addition, it will have its own meaning if research is conducted on local small and mediumsized businesses in addition to the corporate publicity exhibition hall centered on large companies.
\end{abstract}

Keywords - Corporate publicity exhibition hall, Exhibition experience, Experience satisfaction, Brand assets, Behavioral intention

\section{INTRODUCTION}

Until the 1990s, Korean companies have used exhibitions only as a means of promoting sales and raising corporate image. The main activity has been to grasp consumer needs and information of new companies and competitors, to secure new markets and potential customers, and to introduce new products. In addition, the characteristics of one-sided information transmission and rapid changes in the consumption environment of radio, TV, and newspapers in the past have difficulty in forming a close relationship between companies and consumers. Focusing on the product promotion function, which is a unique role of the corporate publicity exhibition hall, is admitted to be retrograde.

Today's corporate publicity exhibition halls not only have their own product promotion functions, but also play the new media of communication through communication activities between companies and consumers, and provide information of their own companies, convenience facilities, and complex cultural

Received:

Reviewed:

Accepted:

* Corresponding Author 
spaces. However, the recognition and research on the corporate publicity exhibition hall is insufficient, and the empirical research on the effect is very lacking.

In this regard, this study tries to examine the effects of exhibition experience on satisfaction, brand assets and consumer behavioral intention in order to suggest the necessity and direction of development of the corporate publicity exhibition hall. In addition, it will identify the advantages and disadvantages of the exhibition experience at the current corporate publicity exhibition hall, and suggest improvement plans and future directions. It will find a way to develop it into a space that can promote intimacy between companies and consumers, and satisfy various demands of consumers through exchange of information and communication, and that can provide cultural services through cutting-edge exhibition and display techniques to consumers and potential customers, and form a local culture that contributes to the region.

\section{Theoretical Background}

\subsection{Corporate Publicity Exhibition Hall}

The corporate publicity exhibition hall means that the subject of the establishment and operation of the exhibition hall is corporate, and is a terminology belonging to the category of the corporate museum. According to the definition specified in the Museum Act, the corporate museum is included in the categories of science museum, industrial technology museum and history museum, and is a special museum that specializes in detailed collections. Jeong-Suk Hyeong(2002) argued that the company museum generally refers to a specialized museum, and is an exhibition facility[1] that specializes in storing information and materials in a specific field.

The charter of the international museum conference defined museum as a facility made to contribute to academic research and social education through display or exhibition for public education and entertainment by various ways of preserving and studying collections of arts, history, fine art, science and technology, and culturally valuable materials and specimens such as botanical garden, zoo and aquarium. It can be said a corporate museum that is based on the cultural domain of these museums.

The corporate publicity exhibition hall is much different from other public institutions and private exhibition halls in its purpose and character. The corporate publicity exhibition hall is an exhibition hall[2] installed and operated as a dimension to improve the corporate image corresponding to the changes in the new management environment and the diversified consumer demands in the relationship between the company and society with the corporate social responsibility. The corporate publicity exhibition hall is being established and developed as a way of managing strategy to ensure that the purpose of the company is to continue to be a successful company rather than the economic goal of profit creation.

Table 1. Types of Corporate Publicity Exhibition Hall According to Nature and Purpose

\begin{tabular}{|c|l|c|l|}
\hline \multirow{4}{*}{\begin{tabular}{c} 
Enterprise \\
publicity \\
\cline { 2 - 4 } $\begin{array}{c}\text { exhibition } \\
\text { hall }\end{array}$
\end{tabular}} & Personality & $\begin{array}{c}\text { Type } \\
\text { Commercial } \\
\text { exhibition }\end{array}$ & $\begin{array}{l}\text { Purpose of corporate sales growth in anticipation of propaganda } \\
\text { effect }\end{array}$ \\
\cline { 2 - 4 } & \multirow{2}{*}{ Purpose } & $\begin{array}{c}\text { Nonprofit } \\
\text { exhibition }\end{array}$ & $\begin{array}{l}\text { Purpose of publicity, cultural enlightenment, education, etc. of } \\
\text { nonprofit institutes. }\end{array}$ \\
\cline { 3 - 4 } & $\begin{array}{c}\text { Permanent } \\
\text { Exhibition Hall }\end{array}$ & $\begin{array}{l}\text { Doing also promotion of corporate image as a memorial hall of } \\
\text { corporate. }\end{array}$ \\
\cline { 3 - 4 } & $\begin{array}{c}\text { Non-permanent } \\
\text { exhibition hall }\end{array}$ & $\begin{array}{l}\text { As one-time short-term exhibition type, an event-based exhibition } \\
\text { that serves as a corporate publicity }\end{array}$ \\
\hline
\end{tabular}

\subsection{Exhibition Experience}

Experience refers to a series of processes[3] obtained through experience. Therefore, the exhibition experience means the experience that is felt through a series of process to meet the desire to see and motivation.

The experience exhibition[4] is an exhibition type based on the proverb, 'When you only listen, you will forget it. When you see, you will remember it. When you act, you will understand it'. Experience exhibition refers to one that visitors themselves interact with exhibitions[5] by planning and practicing their own exhibition behavior in the exhibition space and causing self motivation. It is also an active 
exhibition where exhibitions and visitors, visitors and exhibition spaces, and exhibition spaces and exhibitions communicate with each other, and an exhibition that cannot be established without the voluntary actions and active participation of visitors. In other words, it is very important in today's exhibition environment as it gives an active meaning of doing something by itself, away from the passive meaning of exhibition[6]. Exhibit experiences induce active participation by stimulating interest and intellectual curiosity to visitors through a new exhibition production method. Visitor's participation aims to enhance the original meaning of the exhibition, which stimulates the viewer's emotion and inputs information due to the experience through five senses[7].

Table 2. Types of Exhibition Experience [8]

\begin{tabular}{|c|l|}
\hline Display type & \multicolumn{1}{c|}{ Contents } \\
\hline $\begin{array}{c}\text { Experience exhibition } \\
\text { (Hands-on) }\end{array}$ & $\begin{array}{l}\text { An exhibition that induces a direct experience with the exhibitions using the five senses, } \\
\text { not just the eyesight. }\end{array}$ \\
\hline $\begin{array}{c}\text { Interactive exhibition } \\
\text { (Interactive) }\end{array}$ & $\begin{array}{l}\text { An exhibition that induces the viewers' active reactions and actions to explore knowledge } \\
\text { and principles through reactions and results to exhibitions }\end{array}$ \\
\hline $\begin{array}{c}\text { Participation exhibition } \\
\text { (Participative) }\end{array}$ & $\begin{array}{l}\text { An exhibition that encourages visitors' voluntary participation by providing a connection } \\
\text { with daily life in an interesting configuration }\end{array}$ \\
\hline $\begin{array}{c}\text { Interesting exhibition } \\
\text { (Entertaining) }\end{array}$ & $\begin{array}{l}\text { An exhibition that encourages visitors' voluntary participation by providing a connection } \\
\text { with daily life in an interesting configuration }\end{array}$ \\
\hline $\begin{array}{c}\text { Mind moving exhibition } \\
\text { (Minds-on, Hearts-on) }\end{array}$ & An exhibition that expands and inspires human perception \\
\hline
\end{tabular}

\subsection{Satisfaction}

As for research on satisfaction, the research on the cause-effects of satisfaction in the aspect of marketing was initiated based on Oliver (1980)'s recognition system of discrepancies with the expectation-performance[9] in the 1980s. Satisfaction is a complex concept[10], which refers to the degree of achieving motivation by basic human needs, as discussed in the behavioral science, and in the lexical sense, is originated from the Latin words 'SARIS' and 'FACERE' meaning filling, or fulfillment.

Visitor's satisfaction is the concept of the overall evaluation of the corporate publicity exhibition hall. Satisfaction degree is the consumption associated with the product and service characteristics or the product and service itself. It can be defined as judgment on the consumption level related with accomplishment that satisfaction is provided to consumers, and as the degree of subjective judgment and evaluation of visitors.

\subsection{Brand Assets}

A brand is not just limited to its name, but also includes psychological value aswell as the physical composition of the product. In addition to the strengths of the product, it has the power to influence independent differentiation and purchasing choice through the consumer's use process, which is expressed as a brand asset.

Entering into the 1980s, asset valuation of a company's brand began to emerge as an important issue. In most cases, brand asset can be guaranteed a profit higher than non-branded products or products in companies, individuals and organizations. It can be said the combination of debt and assets[11] related to brand names or symbols that are consistent, strong and differentiated compared to other competitors.

The research on the components that form brand asset was conducted centering around he researches of Aaker(1991) and Keller(1993)[12] [13], and this study also composed elements of brand asset based on the brand asset component model of these two scholars.

\subsection{Behavioral Intention}

Behavioral intention has been interpreted in various ways according to each research field or object of social science, and has been actively researched as a key element in the marketing field[14] targeting consumer behavior.

Behavioral intention is a subjective function in which beliefs and attitudes are acted upon, and intention is perceived as an intermediate variable between individual attitudes and behaviors, and means 
individual's subjective state[15]. Therefore, the behavioral intention in the exhibition experience can be defined as the individual's will and belief that the viewers will express a specific future behavior before forming an attitude toward an object.

\section{Research Design}

\subsection{Survey Subject and Research Model}

In order to conduct this study, a survey was conducted on the visitors to a domestic publicity exhibition hall in a personal branch filling way. In order to compare and examine the effect of exhibition experience, which is an independent variable, on experience satisfaction, brand asset and behavioral intention based on literary researches and previous studies, the research model is set as shown in [Figure $1]$.

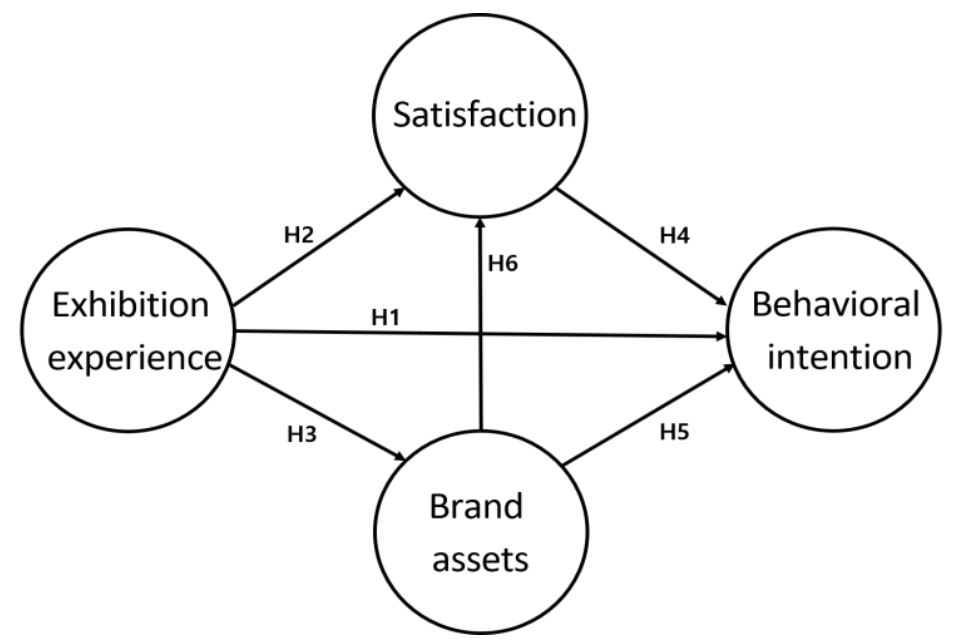

Fig. 1 Research Model

\subsection{Research Hypothesis}

In this study, the following six hypotheses were established based on theoretical considerations on the premise that the exhibition experience in the corporate publicity exhibition hall will have a positive effect on behavioral intention.

Hypothesis 1. Exhibition experience will have a positive effect on behavioral intention.

Hypothesis 2. Exhibition experience will have a positive effect on satisfaction.

Hypothesis 3. Exhibition experience will have a positive effect on brand asset.

Hypothesis 4. Satisfaction will have a positive effect on behavioral intention.

Hypothesis 5. Brand asset will have a positive effect on behavioral intention.

Hypothesis 6. Brand asset will have a positive effect on satisfaction.

\section{Empirical Analysis}

\subsection{Demographic Characteristics of Sample Target}

According to the gender of the sample, 223 men (56.2 percent) and 174 women (43.8 percent), 40 people under 20 (10.1 percent), 80 people in their 30s (20.2 percent), 201 people in their 40 s $(50.6$ percent), 60 people in their 50s (15.1 percent), and 16 visitors in their $60 \mathrm{~s}$ and older (4.0 percent) accounted for 69.7 percent of the total.

According to the survey, 116 people (29.2 percent) graduated from high school, 241 people (60.7 percent) graduated from college, and 40 people (10.1 percent) graduated from graduate school, the higher the willingness to visit the museum. 
The number of visits was 277 (69.8 percent), 112 (19.2 percent), and 8 (2.0 percent) after the first visit, indicating that the rate of revisit after the first visit was significantly lower, while the rate of stay was 48 people (12.1 percent), 202 people (50.9 percent), and 147 people (37.0 percent) for one to two hours, from more than 30 minutes to less than two hours, according to the survey.

The purpose of the visit was 28 people $(7.1 \%)$ to purchase products, 95 people $(23.9 \%), 28$ people $(7.1 \%)$ to experience products, 151 people $(38.0 \%)$ to acquire information and learn information, and 95 people $(23.9 \%)$ to visit each other, and all types of visits were found to be individual visits.

\subsection{Exploratory Factor Analysis and Reliability Analysis}

The KMO measure was .771, which satisfied the criteria of sample suitability, and the Bartlett spherical test (Chi-square $=13372.766$, degrees of freedom $=946$, significance probability $=.000$ ) was also appropriate for the analytical model.

The commonality of the measurement variables was .908 to .511 , and all were 0.5 or more. The extracted factors were 11 including entertainment experience, deviation experience, aesthetic experience, educational experience, exhibition experience satisfaction, brand recognition, brand association, perceived quality, recommendation intention and return intention. The total explanatory variable by these factors was $76.236 \%$

The reliability among the extracted factors was that entertainment experience was .882 , deviation experience was .933 , aesthetic experience was .715 , education experience was .844 , exhibition experience satisfaction was .927 , exhibition service satisfaction was .885 , brand recognition was .734 , brand association was .793, recommendation intention was .901, and the return intention was .953 .

\subsection{Confirmatory Factor Analysis}

The overall confirmatory factor analysis model of this study shows that $\mathrm{CMIN}=1280.435(\mathrm{p}<0.001)$, $\mathrm{df}=531, \mathrm{CMIN} / \mathrm{df}=2.411, \mathrm{GFI}=.858, \mathrm{AGFI}=.821, \mathrm{NFI}=.844, \mathrm{RMR}=.044, \mathrm{RMSEA}=.060$, and $\mathrm{CFI}=0.928$ as shown in [Table 3], confirming that the confirmatory factor analysis model considering the correlation between concepts can be seen as a suitable level. On the other hand, the results of the confirmatory factor analysis on the whole unit of variables are shown in [Table 4], and it was found that 48 variables were first input in the exploratory factor analysis, but 13 variables were removed as a result of the confirmatory factor analysis.

Table 3. Conformance Index of Confirmatory Factor Analysis

\begin{tabular}{|c|c|c|c|c|c|c|c|c|c|c|c|}
\hline & CMIN & DF & RMR & GFI & AGFI & NFI & RFI & IFI & TLI & CFI & RMSEA \\
\hline Results & $1,280.435$ & 531 & .044 & .858 & .821 & .884 & .862 & .928 & .914 & .928 & .060 \\
\hline Criteria & \multicolumn{2}{|c|}{$\mathrm{X}^{2} / \mathrm{df} \leq 3$} & $\leq .05$ & $\geq .9$ & $\geq .9$ & $\geq .9$ & $\geq .9$ & $\geq .9$ & $\geq .9$ & $\geq .9$ & $\leq .05$ \\
\hline
\end{tabular}

Table 4. Results of Confirmatory Factor Analysis of all the Unit Variables

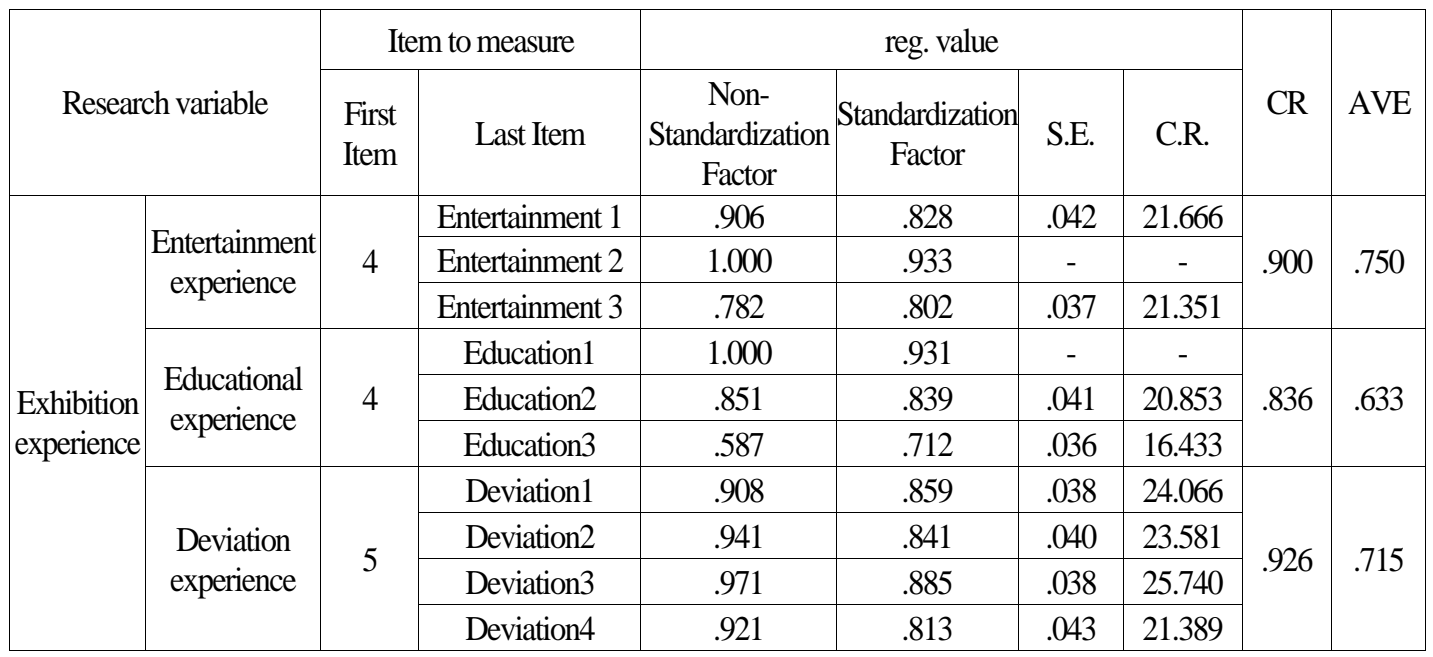


A Study On The Relationship Between Exhibition Experience And Behavioral Intention, And The Mediating Effect Of Satisfaction And Brand Assets In Corporate Promotion Exhibition Halls

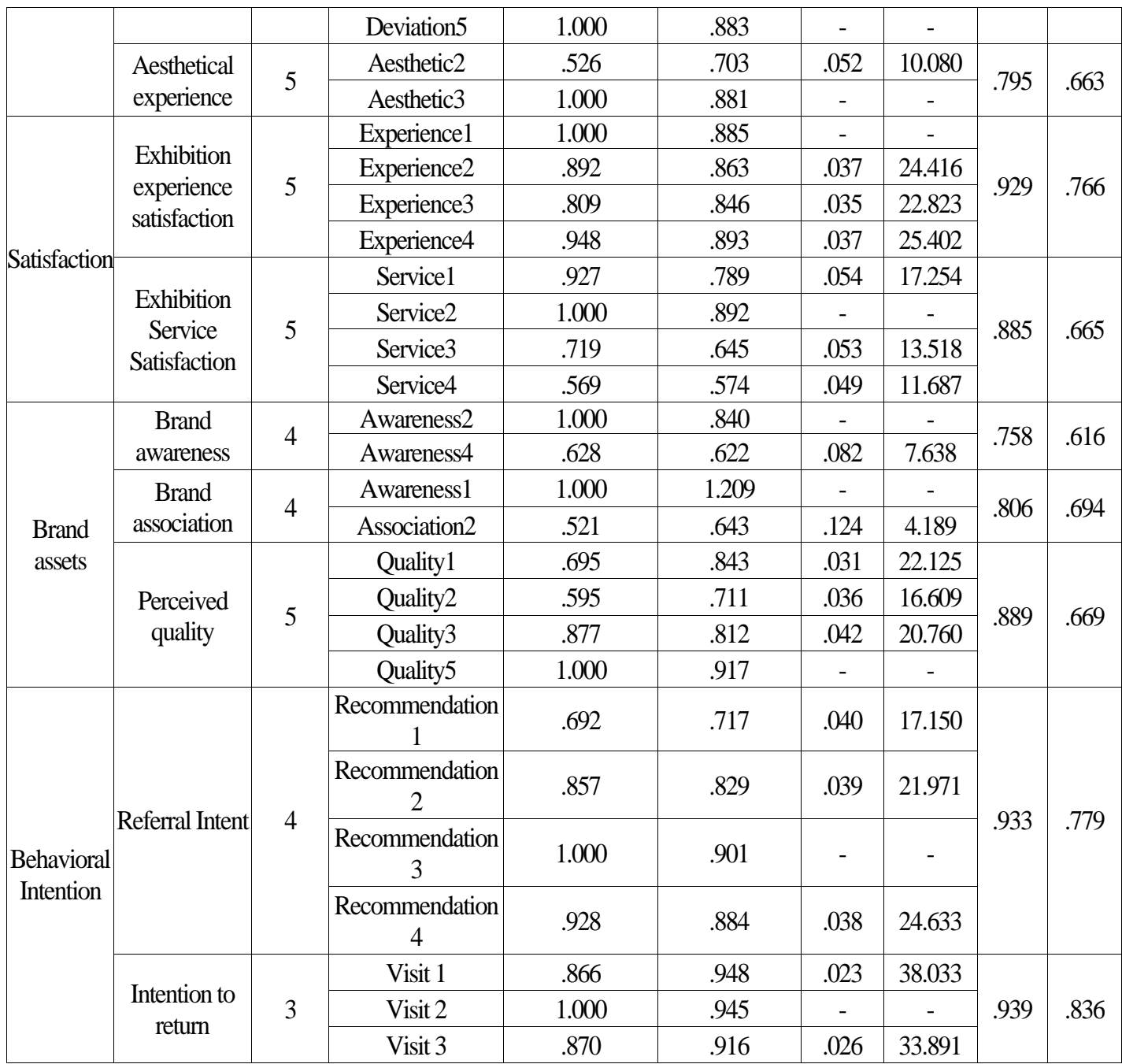

\subsection{Confirmatory Factor analysis}

As shown in [Table 5], the results of correlation analysis of this study showed that most of the items were significant, and suitability of the data is secured as the correlation coefficient value was not more than .7, and there was no problem in the multicollinearity raised in the multiple regression analysis. The average variance extraction(AVE) was determined by whether the squared value of the correlation coefficient between the concepts exceeded the criteria in order to identify the discriminant validity of this study.

Table 5. Correlation Analysis

\begin{tabular}{|c|c|c|c|c|c|c|c|c|c|c|c|c|}
\hline Variable & Entertainment & $\begin{array}{l}\text { Educational } \\
\text { experience }\end{array}$ & $\begin{array}{l}\text { Deviation } \\
\text { experience }\end{array}$ & $\begin{array}{l}\text { Aesthetical } \\
\text { experience }\end{array}$ & $\begin{array}{l}\text { Experience } \\
\text { satisfaction }\end{array}$ & $\begin{array}{c}\text { Service } \\
\text { satisfaction }\end{array}$ & $\begin{array}{c}\text { Brand } \\
\text { awareness }\end{array}$ & \begin{tabular}{|c|} 
Brand \\
association
\end{tabular} & $\begin{array}{l}\text { Perceivec } \\
\text { quality }\end{array}$ & $\begin{array}{c}\text { Referral } \\
\text { Intent }\end{array}$ & $\begin{array}{l}\text { Intention } \\
\text { to return }\end{array}$ & AVE \\
\hline Entertainment & 1 & & & & & & & & & & & .750 \\
\hline $\begin{array}{l}\text { Educational } \\
\text { experience }\end{array}$ & $\begin{array}{l}.065 \\
(.004)\end{array}$ & 1 & & & & & & & & & & 633 \\
\hline $\begin{array}{l}\text { Deviation } \\
\text { experience }\end{array}$ & $\begin{array}{l}.338 * * \\
(.114)\end{array}$ & $\begin{array}{l}-.064 \\
(.004)\end{array}$ & 1 & & & & & & & & & .715 \\
\hline $\begin{array}{l}\text { Aesthetical } \\
\text { experience }\end{array}$ & $\begin{array}{c}.077 \\
(.005)\end{array}$ & $\begin{array}{l}.055 \\
(.003)\end{array}$ & $\begin{array}{l}.035 \\
(.001)\end{array}$ & 1 & & & & & & & & .663 \\
\hline $\begin{array}{c}\text { Exhibit } \\
\text { experience } \\
\text { satisfaction }\end{array}$ & $\begin{array}{l}.241 * * \\
(.058)\end{array}$ & $\begin{array}{l}-.100 * \\
(.010)\end{array}$ & $\begin{array}{l}.261 * * \\
(.068)\end{array}$ & $\begin{array}{l}-.029 \\
(.000)\end{array}$ & 1 & & & & & & & .766 \\
\hline $\begin{array}{c}\text { Exhibit } \\
\text { service } \\
\text { satisfaction }\end{array}$ & $\begin{array}{l}-.031 \\
(.000)\end{array}$ & $\begin{array}{l}.355^{* *} \\
(.126)\end{array}$ & $\begin{array}{l}-.058 \\
(.003)\end{array}$ & $\begin{array}{l}.323^{* *} \\
(.104)\end{array}$ & $\begin{array}{l}-.149 * * \\
(.022)\end{array}$ & 1 & & & & & & .665 \\
\hline
\end{tabular}




\begin{tabular}{|c|c|c|c|c|c|c|c|c|c|c|c|c|}
\hline $\begin{array}{c}\text { Brand } \\
\text { awareness }\end{array}$ & $\begin{array}{l}-.019 \\
(.000)\end{array}$ & $\begin{array}{l}-.039 \\
(.001)\end{array}$ & $\begin{array}{l}-.031 \\
(.000)\end{array}$ & $\begin{array}{l}.316^{* *} \\
(.099)\end{array}$ & $\begin{array}{l}-.015 \\
(.000)\end{array}$ & $\begin{array}{l}.188 * * \\
(.035)\end{array}$ & 1 & & & & & .616 \\
\hline $\begin{array}{c}\text { Brand } \\
\text { association }\end{array}$ & $\begin{array}{c}.002 \\
(.000)\end{array}$ & $\begin{array}{l}-.132^{*} \\
(.017)\end{array}$ & $\begin{array}{c}.030 \\
(.000)\end{array}$ & $\begin{array}{l}.217 * * \\
(.047)\end{array}$ & $\begin{array}{l}-.047 \\
(.002)\end{array}$ & $\begin{array}{l}.183 * * \\
(.033)\end{array}$ & $\begin{array}{l}.675^{* *} \\
(.455)\end{array}$ & 1 & & & & .694 \\
\hline $\begin{array}{l}\text { Perceived } \\
\text { quality }\end{array}$ & $\begin{array}{c}.037 \\
(.001)\end{array}$ & $\begin{array}{c}.088 \\
(.007)\end{array}$ & $\begin{array}{l}-.033 \\
(.001)\end{array}$ & $\begin{array}{l}.424 * * \\
(.179)\end{array}$ & $\begin{array}{l}-.107 * \\
(.011)\end{array}$ & $\begin{array}{l}.366 * * \\
(.133)\end{array}$ & $\begin{array}{l}.257^{*} \\
(.066)\end{array}$ & $\begin{array}{l}.236^{*} \\
(.055)\end{array}$ & 1 & & & 669 \\
\hline $\begin{array}{c}\text { Referral } \\
\text { Intent }\end{array}$ & $\begin{array}{l}.453^{* *} \\
(.205)\end{array}$ & $\begin{array}{l}-.036 \\
(.001)\end{array}$ & $\begin{array}{l}.297 * * \\
(.088)\end{array}$ & $\begin{array}{c}.064 \\
(.004)\end{array}$ & $\begin{array}{l}.429 * * \\
(.184)\end{array}$ & $\begin{array}{l}.-111^{*} \\
(.012)\end{array}$ & $\begin{array}{l}-.012 \\
(.000)\end{array}$ & $\begin{array}{l}-.026 \\
(.000)\end{array}$ & $\begin{array}{c}.017 \\
(.000)\end{array}$ & 1 & & .779 \\
\hline $\begin{array}{l}\text { Intention to } \\
\text { return }\end{array}$ & $\begin{array}{c}.057 \\
(.003)\end{array}$ & $\begin{array}{l}.156^{* * *} \\
(.024)\end{array}$ & $\begin{array}{c}.013 \\
(.000)\end{array}$ & $\begin{array}{l}.363 * * \\
(.131)\end{array}$ & $\begin{array}{l}-.029 \\
(.000)\end{array}$ & $\begin{array}{l}.388 * * \\
(.150)\end{array}$ & $\begin{array}{c}.086 \\
(.007)\end{array}$ & $\begin{array}{c}.056 \\
(.003)\end{array}$ & $\begin{array}{l}.454 * * \\
(.206)\end{array}$ & $\begin{array}{l}.090 \\
(.008)\end{array}$ & 1 & .836 \\
\hline
\end{tabular}

The value in $(\mathrm{)})$ is the square root of the correlation coefficient, $*$ p.<.05, **p<.001

In the results of verification using the square of the correlation coefficient for each factor, the discriminant validity of each concept can be said to be secured favorably as the result value of squared correlation coefficient of entertainment experience, education experience, deviation experience, aesthetic experience, exhibition experience satisfaction, exhibition service satisfaction, brand awareness, brand association, perceived quality, recommendation intention, and revisit intention.

\subsection{Hypothesis Test}

4.5.1. Fitness of Research Model: The structural equations were set up using AMOS for the measurement model that introduced the measurement variables into the conceptual research model. In this study, the fitness of the model was evaluated by using CMIN, GFI, AGFI, NFI, TLI, RMR, and RMSEA. Generally, it is evaluated as a good model when GFI, AGFI, NFI, and TLI are 0.8 to 0.9 or more, and RMR and RMSEA are 0.05 to 0.08 or less. Based on this, the results of the structural equation model suitability presented in this study are shown in [Table 6]. As a result of testing this model, the suitability index showed that Q-value was 2.364, which is smaller than the recommended acceptance level of 3, GFI was .968 and TLI (Lisrel's NNFI) was .973, which was over 0.90 , the suitability index of GFI and TLI, showing satisfaction, and the RMSEA value was also .059, which is included in the suitability index of 0.05 to 0.08 , indicating the level of satisfaction. Therefore, the hypothesis test was conducted by judging that the relational model presented in this study is consistent with the analytical data obtained in reality on the satisfactory level.

Table 6. Fitness of Research Model

\begin{tabular}{|c|c|c|}
\hline Suitability & Recommended acceptance level & Analysis Results \\
\hline CMIN $\left(\mathrm{X}^{2}\right)$ & & 68.566 \\
\hline DF & & 29 \\
\hline Q(CMIN/DF $)$ & $\leq 3$ & 2.364 \\
\hline P & $\geq .05$ & .000 \\
\hline GFI & $\geq .9$ & .968 \\
\hline AGFI & $\geq .9$ & .931 \\
\hline NFI & $\geq .9$ & .976 \\
\hline TLI & $\geq .9$ & .973 \\
\hline RMR & $\leq .05$ & .033 \\
\hline RMSEA & $\leq .05$ & .059 \\
\hline
\end{tabular}

4.5.2. Results of Verification of Structural Equation Model: The structural equation model was set up for the research model set in this study, and the analysis results of the structural equation model in this study are shown in [Figure 2].

Followings are the results of analysis of the structural equation model. First, the variables influencing the exhibition experience are entertainment experience, education experience, deviation experience, and aesthetic experience. The most influential variables were educational experience, followed by entertainment experience, aesthetic experience, and deviation experience. Second, the variables influencing satisfaction were exhibited exhibition satisfaction and exhibition service satisfaction. Among the two variables, exhibition service satisfaction was the more influencing variable. Third, the variables influencing brand asset are brand recognition, brand association, and perceived quality. The most influencing variable was brand association, followed by brand awareness and perceived quality. Lastly, 
the variables influencing behavioral intention, which are dependent variables, were recommendation intention and revisit intention, and the more influential variable was revisit intention.

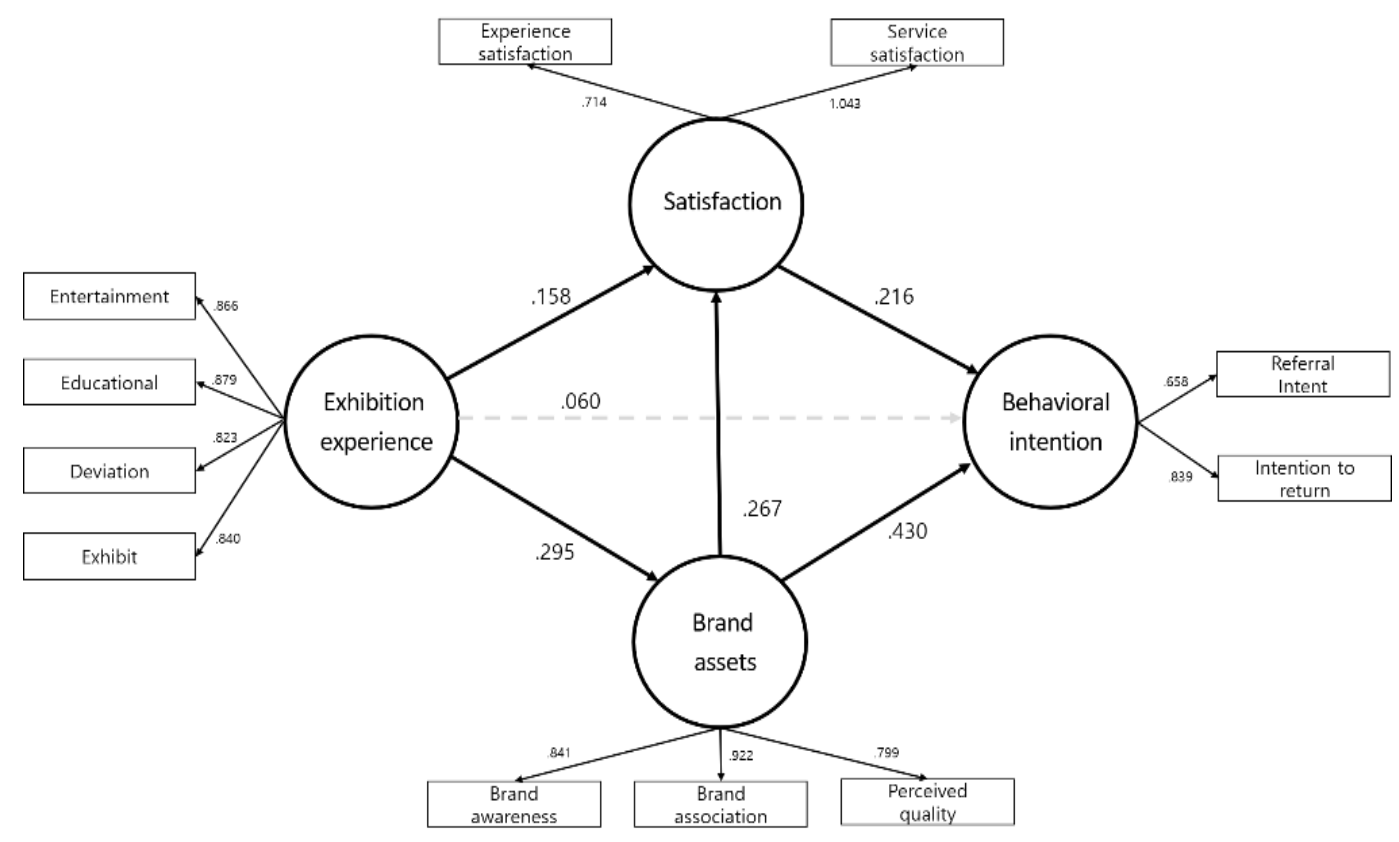

Fig. 2 Path Coefficient Result Value of Structural Equation Model

Table 7. Hypothesis test results

\begin{tabular}{|c|c|c|c|c|c|c|c|c|c|}
\hline \multicolumn{4}{|c|}{ Route } & \multirow{2}{*}{$\begin{array}{c}\text { Non- } \\
\text { standardization } \\
\text { Coefficient }\end{array}$} & \multirow{2}{*}{$\begin{array}{c}\text { Standardization } \\
\text { Coefficient }\end{array}$} & \multirow{2}{*}{$\begin{array}{l}\text { SE } \\
.045\end{array}$} & \multirow{2}{*}{$\begin{array}{l}\text { C.R } \\
1.121\end{array}$} & \multirow{2}{*}{$\begin{array}{c}P \\
262\end{array}$} & \multirow{2}{*}{$\begin{array}{c}\begin{array}{c}\text { Adoption } \\
\text { or not }\end{array} \\
\text { Dismiss }\end{array}$} \\
\hline H1 & $\begin{array}{l}\text { Exhibition } \\
\text { experience }\end{array}$ & $\rightarrow$ & $\begin{array}{l}\text { Behavioral } \\
\text { Intention }\end{array}$ & & & & & & \\
\hline $\mathrm{H} 2$ & $\begin{array}{l}\text { Exhibition } \\
\text { experience }\end{array}$ & $\rightarrow$ & Satisfaction & .177 & .158 & .055 & 3211 & $.001^{* * * *}$ & Adoption \\
\hline $\mathrm{HB}$ & $\begin{array}{l}\text { Exhibition } \\
\text { experience }\end{array}$ & $\rightarrow$ & $\begin{array}{l}\text { Brand } \\
\text { Asset }\end{array}$ & 289 & 295 & .053 & 5.473 & .000 k*k & Adoption \\
\hline $\mathrm{H} 4$ & Satisfaction & $\rightarrow$ & $\begin{array}{l}\text { Behavioral } \\
\text { Intention }\end{array}$ & .161 & 216 & .041 & 3.962 & $.000^{k+k}$ & Adoption \\
\hline $\mathrm{H} 5$ & $\begin{array}{l}\text { Brand } \\
\text { Asset }\end{array}$ & $\rightarrow$ & $\begin{array}{l}\text { Behavioral } \\
\text { Intention }\end{array}$ & 369 & .430 & .049 & 7.455 & $.000 * k * k$ & Adoption \\
\hline $\mathrm{H} 6$ & $\begin{array}{l}\text { Brand } \\
\text { Asset }\end{array}$ & $\rightarrow$ & Satisfaction & 307 & 267 & .058 & 5306 & $.000 * * * *$ & Adoption \\
\hline
\end{tabular}

4.5.3. Mediating Effect Verification Using Boost-Strapping: This study is a method testing significance statistically for verifying the mediating effect between the exhibition experience, in which satisfaction and brand equity are independent variables, and the behavioral intention as a dependent variable. Using the bootstrapping method of structural equation model analysis, the results of verifying direct, indirect and total effects of the brand assets and satisfaction as parameters are shown in [Table 8].

The results of the analysis are characterized that the indirect effect of satisfaction is higher than the indirect effect of brand asset between the exhibition experience and behavioral intention, and the brand asset is higher than satisfaction in the total effect as well. In addition, the interrelationship between the exhibition experiences as an independent variable and the behavioral intention as a dependent variable was insignificant through the hypothesis verification and the mediation effect verification using the 
bootstrapping, while the interrelationship through satisfaction and brand asset as mediating variables was significant.

Table 8. Verification of Direct, Indirect, and Total Effect Using Boot-Strapping

\begin{tabular}{|c|c|c|c|c|c|c|c|}
\hline \multicolumn{5}{|c|}{ Route } & Direct Effect & In-direct Effect & Total Effect \\
\hline \multirow{3}{*}{$\begin{array}{l}\text { Exhibition } \\
\text { experience }\end{array}$} & \multirow{3}{*}{$\rightarrow$} & Satisfaction & \multirow{3}{*}{$\rightarrow$} & \multirow{3}{*}{$\begin{array}{l}\text { Behavioral } \\
\text { Intention }\end{array}$} & $.158 * * *(.004)$ & $.079 * * *(.003)$ & $.236 * * *(.003)$ \\
\hline & & Brand Asset & & & $.295 * * *(.005)$ & $.178 * * *(.006)$ & $.473 * * *(.005)$ \\
\hline & & - & & & $.060(.205)$ & - & $.060(.205)$ \\
\hline \multirow{2}{*}{ Brand Asset } & \multirow{2}{*}{$\rightarrow$} & Satisfaction & \multirow{2}{*}{$\rightarrow$} & \multirow{2}{*}{$\begin{array}{l}\text { Behavioral } \\
\text { Intention }\end{array}$} & $.267 * * *(.002)$ & $.058 * * *(.002)$ & $.325^{* * *}(.002)$ \\
\hline & & - & & & $.430 * * *(.005)$ & - & $.430 * * *(.005)$ \\
\hline Satisfaction & $\rightarrow$ & - & $\rightarrow$ & $\begin{array}{l}\text { Behavioral } \\
\text { Intention }\end{array}$ & $.216^{* * * *}(.008)$ & - & $.216^{* * *(.008)}$ \\
\hline
\end{tabular}

$* * * \mathrm{p}<.01$

The value in ( ) is the Two Tailed Significance value by the Boot-Straping Analysis.

\section{Conclusion}

In order to understand the effect of the exhibition experience on satisfaction and behavioral intention at the corporate publicity exhibition hall, this study analyzed empirically the effect of four experience elements (entertainment experience, education experience, deviation experience, and aesthetic experience) proposed by Pine \& Gilmore on satisfaction and behavioral intention. The implications based on the research results are as follows.

First, as a result, the corporate publicity exhibition hall did not have much effect on the behavioral intention of customers simply by exhibiting and viewing. This might indicate that companies that operate or prepare to open corporate publicity exhibition hall should avoid such simple experiences or simple viewing facilities.

Second, the corporate publicity exhibition hall cannot induce customers' behavior simply by exhibiting experiences. If the corporate publicity exhibition hall is operated in combination with the brand assets of the company presented in this research or tangible and intangible assets of other companies, more efficient results will be anticipated.

Third, as derived from the results of the study, corporate product brands are exposed to consumers daringly, and they work very sensitive to consumers, affecting their behavioral intention. The positive image of a product brand will lead to satisfaction and behavioral intention, which in turn will affect the company's sales growth. Therefore companies should be very careful in product brand management.

The academic significance of this study is in that it investigate the relationship between satisfaction, brand assets, and behavioral intention through the exhibition experience in the corporate publicity exhibition hall by analyzing their structure empirically. In addition, it is expected that it can be used as a practical basic material that can be more practical in producing exhibition experiences when newly opening a corporate publicity exhibition hall or remodeling the existing one.

It will have its own meaning, if follow-up studies proceed with various variables such as human and material factors of the corporate publicity exhibition hall including information desk and guide which are the contact points with customers, as well as four contact points in order to provide the best exhibition experience to visitors to the corporate publicity exhibition hall.

\section{ACKNOWLEDGMENTS}

This study is based on the researcher's dissertation with different research methodologies.

\section{REFERENCES}


[1] Jung-Suk. Hyeong, "Structure of Exhibition Scenario and Space Arrangement Programming in the Enterprise Museum”, M.S.thesis, Seong-Gyun-Gwna University, 2002, p.5.

[2] Chong-Seong. Kim, "A Study on the Consumer's Consciousness of Enterprise Museum”, M.S thesis, Yeon-Se University, 2003, p.20.

[3] Gum-Ho. Lee, "A Study on the Effect of Traditional Cultural Experience on Touring Satisfaction and Behavioral Intention”, Ph.D Se-Han University, 2017, p.23.

[4] Michael. B, Exhibitions in Museums, Seoul, Ye-Gyeong, 2006, p.104.

[5] Yang-Ju. Kim, Joo-Yun. Kim \& Jong-Se. Lee, "Research on Space Experience Elements According to Behavioral Characteristics in Exhibition Space at Children`s Museum", Journal of the Korea Instiute of Spatial Design, Vol.7 No.4 (2012):19.

[6] Yeon-Kyung. Lee, "A Study on the Exhibition Space Planning of Science Museum for Experience Learning", M.S thesis Hong-Ik University, 1990, p.27.

[7] Won-Gil. Kim, "A study on the characteristics of medium and production for improved sensibility interface of exhibit space", M.S thesis Hong-Ik University, 2003, p.45.

[8] Doo-Ri. Song, "A study on the characteristic of the direction for an exhibition according to the type of experience exhibition of children, M.S thesis Kook-Min University, 2009, p.12.

[9] Oliver, R. L, "A Cognitive Model of the Antecedents and Consequences of Satisfaction Decisions", Journal of Marketing Research, 17-November (1980):460-469.

[10] Min-Chae Jeung, "The impact that educational attributes, brand value, and properties of choice influence to tourism satisfaction and behavioral intention in historical and cultural sites", Ph.D Kyung-Hee University, 2009, p.28.

[11] Min-Seok. Kwak \& Kwang-Min. Cho, "The Relationships Among Brand Equity, Brand Value, Customer Satisfaction, Brand Attitude, and Revisit Intention in Golf", Korean journal of physical education, Vol.50 No.1 (2011):147-160.

[12] Aaker, "The Value of brand equity”, The Journal of Business Strategy, Vol.38 No.3 (1991):102-120.

[13] Keller K. L, "Conceptualizing, Measuring and Managing Customer-based Brand Equity", Journal of Marketing, Vol.57 No.1 (1993):1-22.

[14] Eun-Hye. Cho, "The impacts of the suitability and attractiveness of the dining space facade on customer awareness and behavior intention", Ph.D Kyong-Gi University, 2015, p.36.

[15] Yung-Kon. Kim, "The relationship among Motive of Visitation, Image of Tourism, Satisfaction, Behavioral Intentions of Visitor Taekeondo festival”, Ph.D Kyung-Hee University, 2009, p.34.

[16] Seung-Wan, Ju, "A Study on the Influences of Exhibition Experience, Satisfaction, Brand Assets and Behavioral Intention," International Journal of Business Policy and Strategy Management, Vol.7 No.1, Jun, (2020), Global Vision Press, pp:31-38,10.21742/IJBPSM.2020.7.1.04

[17] Hyun-Kyung Lee. "Stressing Sensorial-Experiential Exhibitions Analysis: Latest \& Hottest Digital Exhibition Trends". International Journal of Art and Culture Technology. Vol. 2. No. 2. Oct. 2018.GVPress. pp:31-38.http://dx.doi.org/10.21742/IJACT.2018.2.2.06

[18] Seung-Wan Ju \& Na-Na Lee, "A Study on the Directing Direction of Exhibition in the Corporate Exhibition Spaces". International Journal of IT-based Management for Smart Business. Vol. 6. No. 1. Jul. 2019.GVPress. pp:1-6.http://dx.doi.org/10.21742/IJITMSB.2019.6.1.01 
[19] Jae Eon Yu. "Understanding Social Innovation from Systemic Perspectives". International Journal of Business Policy and Strategy Management. Vol. 4. No. 2. Nov. 2017.GVPress. pp:3338.http://dx.doi.org/10.21742/IJBPSM.2017.4.2.05

[20] Seung-Wan, Ju. "Study on Effectiveness Enhancement of On-line Exhibition of Corporate Publicity Exhibition Hall". International Journal of IT-based Business Strategy and Management. Vol. 3. No. 2. Dec. 2017.GVPress. pp:9-14.http://dx.doi.org/10.21742/IJBSM.2017.3.2.02

[21] Yo Seb Kim \& Yeong Hun Yeo. "Study on the Trends in Life Satisfaction among the Elderly". International Journal of Elderly Welfare Promotion and Management. Vol. 3. No. 1. May. 2019.GVPress. pp:7-12.http://dx.doi.org/10.21742/IJEWPM.2019.3.1.02

[22] Won-Geun So \& Ha-Kyun Kim. "The Factors of Social Enterprise Support Effect to Social Performance and Job Satisfaction”. Asia-pacific Journal of Psychology and Counseling. Vol. 1. No. 1. Apr. 2017.GVPress. pp:7-12.http://dx.doi.org/10.21742/APJPC.2017.1.1.02

[23]Ramya Jain, "Basic Branding Concepts: Brand Identity, Brand Image and Brand Equity", International Journal of Sales \& Marketing Management Research and Development (IJSMMRD), Vol. 7, Issue 4, pp, 1-8

[24]Suvarna Patil \& Arun Handa, "Counterfeit Luxury Brands Scenario in India: An Empirical Review", International Journal of Sales \& Marketing Management Research and Development (IJSMMRD), Vol. 4, Issue 2, pp, 1-8

[25]Rekha U. Menon \& Pramod M., “Alternate Modes of Corporate Brand Endorsement: Need of the Hour in Indian Context", International Journal of Business and General Management (IJBGM), Vol. 5, Issue 3, Apr - May 2016; 29-36

[26]Renu Rana \& Shikha Kapoor, "Exploring the Contribution of Employer Branding in Corporate Image Building", International Journal of Business and General Management (IJBGM), Special Edition, pp ; 21-32

[27]M.C. Saravanakumar, \&R. Rajendran, "A Study on Brand Awareness in Rural Area with Special Reference to Health Food Drinks", IMPACT: International Journal of Research in Business Management (IMPACT: IJRBM), Vol. 4, Issue 3,pp, 113- 118

[28]Armah-Bempong Eric \& Kofi Owiredu Ghorman, "The Effects of Branding in the Marketing of Locally Manufactured Products in Ghana- A Case of Chocho Industrires Limited", International Journal of Sales \& Marketing Management Research and Development (IJSMMRD), Vol. 7, Issue 4, pp, 77-88 